\title{
Carbon and nitrogen content in granulometric fractions of organic matter in soil aggregates under no-tillage and conventional tillage planting systems for onions
}

\author{
Contenido de carbono y nitrógeno en fracciones granulométricas de materia \\ orgánica en agregados de suelo sin labranza y sistemas convencionales de siembra \\ para cebollas
}

Luiz Henrique dos Santos ${ }^{1}$, Arcângelo Loss ${ }^{1 *}$, Ludiana Canton ${ }^{2}$, Monique Souza ${ }^{1}$, Guilherme Wilbert Ferreira $^{1}$, Claudinei Kurtz ${ }^{3}$, Gustavo Brunetto ${ }^{4}$; Cledimar Rogério Lourenzi ${ }^{1}$, Paulo Emílio Lovato ${ }^{1}$, Jucinei José Comin 1

\begin{abstract}
Carbon $(\mathrm{C})$ and nitrogen $(\mathrm{N})$ content in granulometric fractions of soil organic matter $(\mathrm{SOM})$ are sensitive indicators of soil quality changes caused by management systems. This study evaluated the $\mathrm{C}$ and $\mathrm{N}$ content in granulometric fractions of SOM of aggregates, an Inceptisol under onion grown in no-till vegetable farming systems (NTVFS) and conventional tillage systems (CTS), comparing them to a secondary forest. Treatments consisted of soil cover crops, monocropped and intercropped with onions grown under NTVFS: spontaneous vegetation, $100 \%$ black oats; $100 \%$ rye; $100 \%$ oilseed radish; oilseed $(14 \%)+$ rye $(86 \%)$ intercrop and oilseed $(14 \%)+$ oats $(86 \%)$ intercrop. The same evaluations were also performed in an area with onions grown under CTS for \pm 37 years, and in secondary forest ( \pm 30 years). Undeformed soil samples were collected from $0-5,5-10$, and $10-20 \mathrm{~cm}$ deep soil layers, and aggregates were subsequently separated $(8.00 \mathrm{~mm}>\varnothing \geq 2.0$ $\mathrm{mm})$. Organic $\mathrm{C}(\mathrm{OC})$ and $\mathrm{N}$ of the granulometric fractions contents were quantified in aggregates, which were subdivided into particulate fractions (POC and PN) and mineral-associated fractions (OCam and Nam). NTVFS promoted protection of SOM at the 0-5 cm depth compared to CTS, as a result of higher POC content. Intercropped oats+oilseed and spontaneous vegetation contributed to an increase in PN content compared to all other treatments under NTVFS. Monocropped and intercroppped oilseed radish caused an increase in Nam, which was more effective than OCam to indicate differences among the systems. Conversion of areas from CTS to NTVFS promotes increases in POC and PN content in the upper soil layer. NTVFS improves the quality of aggregates, and it may reduce damage caused by CTS.

Keywords: Cover crops, intercropping, particulate carbon, particulate nitrogen, Allium cepa.
\end{abstract}

\section{RESUMEN}

El contenido de carbono $(C)$ y nitrógeno $(N)$ en las fracciones granulométricas de la materia orgánica del suelo (MOS) es un indicador sensible de los cambios en la calidad del suelo causados por los sistemas de manejo. Este estudio evaluó el contenido de Cy N en fracciones granulométricas de la MOS de agregados, en un Inceptisol bajo cebolla cultivada en sistema de cultivo de vegetales sin labranza (SCVSL) y sistema de labranza convencional (SLC), comparándolos con un bosque secundario. Los tratamientos consistieron en cultivos de cobertura del suelo, monocultivos y consorciados con cebollas cultivadas bajo SCVSL: vegetación espontánea, 100\% de avena negra; $100 \%$ de centeno; $100 \%$ nabo forrajero; consorcio de nabo $(14 \%)+$ centeno $(86 \%)$, consorcio de nabo $(14 \%)+$ avena ( $86 \%)$. Las mismas evaluaciones se realizaron en un área con cebollas cultivadas bajo SLC durante \pm 37 años, y en un bosque secundario ( \pm 30 años). Se recogieron muestras de suelo no deformadas de capas de suelo de 0-5, 5-10 y 10-20 cm de profundidad, y los agregados se separaron posteriormente $(8.00 \mathrm{~mm}>\emptyset \geq 2.0 \mathrm{~mm}$ ). Las cantidades de C orgánico $(C O)$ y $N$ de las fracciones granulométricas se cuantificaron en agregados, que se subdividieron en fracciones particuladas (PCO y PN) y fracciones asociadas con minerales (COam y Nam). SCVSL promovió la protección de MOS a una profundidad de 0-5 cm en comparación con SLC, como resultado de un mayor contenido de POC. La avena consorciada con nabo y la vegetación espontánea contribuyeron a un aumento en el contenido de PN en comparación con todos los otros tratamientos bajo SCVSL. El nabo forrajero en monocultivo y consorciado causó un aumento en Nam, que fue más efectivo que el COam para indicar diferencias entre los sistemas. La conversión de áreas de SLC a SCVSL promueve aumentos en el contenido de PCO y PN en la capa superior del suelo. SCVSL mejora la calidad de los agregados, y puede reducir el daño causado por SLC.

Palabras clave: cultivos de cobertura, cultivos consorciados, carbón particulado, nitrógeno particulado, Allium cepa

1 Programa de Pós-graduação em Agroecossistemas (PGA), Universidade Federal de Santa Catarina (UFSC). Itacorubi, Florianópolis, Santa Catarina, Brasil.

2 Programa de Pós-graduação em Recursos Genéticos Vegetais (RGV), Universidade Federal de Santa Catarina (UFSC). Itacorubi, Florianópolis, Santa Catarina, Brasil.

3 Empresa de Pesquisa Agropecuária e Extensão Rural de Santa Catarina. Ituporanga, Santa Catarina, Brasil.

4 Programa de Pós-graduação em Ciência do Solo, Universidade Federal de Santa Maria. Santa Maria, Rio Grande do Sul, Brasil.

* Corresponding author: arcangelo.loss@ufsc.br.

Fecha de Recepción: 18 junio, 2018.

Fecha de Aceptación: 13 septiembre, 2018.

DOI: 


\section{Introduction}

Onions (Allium cepa) are an important vegetable in Brazil; the southern area accounts for $47 \%$ of national production. In the state of Santa Catarina (SC), the largest national producer since 1990, onion crops are grown mostly under conventional tillage system (CTS), with strong environmental impact, especially due to erosion and other soil-degrading processes (Acate, 2014; Loss et al., 2015).

An alternative to soil CTS is the no-tillage farming system (NTFS), which here is referred to as no-tillage vegetable farming system (NTVFS). Soil quality is improved under this system by the continuous supply of cover crop residues on the soil surface and by soil tillage restricted to the planting row. The use of NTVFS tends to maintain and/or to increase soil carbon and nitrogen content, especially for CTS-cultivated soils converted to NTVFS (Epagri, 2013; Loss et al., 2011; 2015).

Total organic carbon (TOC) and total nitrogen (TN) content, as well as granulometric fractions of soil organic matter (SOM), expressed as particulate $\mathrm{OC}$ and particulate $\mathrm{N}$ (POC and $\mathrm{PN}$, respectively) and mineral-associated OC and N (OCam and Nam, respectively), are useful indicators of soil quality and may indicate environmental impacts (Loss et al., 2011; Luce et al., 2013; Winck et al., 2014).

POC and PN ( $>53 \mu \mathrm{m})$ derive from residues of plants and hyphae, which remain in the soil due to physical protection by aggregates. For this reason they constitute labile fractions, with a greater recycling rate of organic constituents (Golchin et al., 1994). According to Luce et al. $(2013,2014)$ and Winck et al. (2014), in systems with a greater amount of shoot and root biomass there is more accumulation of carbon and nitrogen in the particulate fraction of SOM. Consequently, POC and PN are more sensitive than TOC or TN as indicators of changes promoted by soil management. According to Luce et al. (2014), after particulate fractions of $\mathrm{C}$ and $\mathrm{N}$ are mineralized by microorganisms they are important sources of mineral $\mathrm{C}$ and $\mathrm{N}$ in agricultural soils.

OCam and Nam $(<53 \mu \mathrm{m})$ are associated with silt $(2-53 \mu \mathrm{m})$ and clay $(0-2 \mu \mathrm{m})$ fractions and interact with the surface of these minerals, creating organomineral complexes that are protected by the soil colloidal fraction (Cambardella \& Elliott, 1992). These fractions depend on the amount of organic material in the particulate fraction (POC and PN), and on the colloidal protection offered by mineral surfaces
(Baldock, 2000). They also have a high degree of humification, and unlike POC and PN they are usually less sensitive to changes in soil management, mainly in the short term (Bayer et al., 2004). The OCam and Nam fractions are very important for microaggregate stabilization, since they are mostly composed of humic substances such as the humic fraction (Cambardella \& Elliott, 1992).

Since SOM content and quality are conditioned by soil use and management, and $\mathrm{C}$ and $\mathrm{N}$ contents in granulometric fractions of SOM are sensitive indicators of changes in soil quality caused by management systems, the aim of this study was to evaluate the $\mathrm{C}$ and $\mathrm{N}$ content in granulometric fractions of soil organic matter of aggregates of an Inceptisol under onion grown in several no-till vegetable farming systems (NTVFS) and conventional tillage systems (CTS), comparing them to a secondary forest area.

\section{Material and Methods}

The study was carried out at EPAGRI (Empresa de Pesquisa Agropecuária e Extensão Rural de Santa Catarina) Experimental Station at Ituporanga, Southern Brazil, located at $27^{\circ} 24^{\prime} 52^{\prime \prime}$ S, $49^{\circ} 36^{\prime}$ 9" $\mathrm{W}$, altitude $475 \mathrm{~m}$. The climate is mesothermal humid subtropical (Cfa), with warm summers and infrequent frosty weather, without a defined dry season, mean annual temperature of $17.6^{\circ} \mathrm{C}$ and mean annual rainfall of $1,400 \mathrm{~mm}$.

The experiment was set up in a Humic Dystrudepts (Soil Survey Staff, 2010) with clay-loam texture (380, 200 and $420 \mathrm{~g} \mathrm{~kg}^{-1}$ clay, silt and sand, respectively) in the $0-10 \mathrm{~cm}$ layer, in an area with a history of onion crops under CTS (plowing and rotary tiller) for around 20 years. The soil was limed in 1996 to raise the water $\mathrm{pH}$ to 6.0 and the minimal onion farming system was implemented, with crop rotation and cover plants (black oats (Avena strigose Schreb.), mucuna (Mucuna aterrima Piper and Tracy), millet (Pennisetum glaucum), crotalaria (Crotalaria juncea) and vetch (Vicia sativa), which was maintained from 1996 to 2007. Afterwards, sweet potatoes (Ipomoea batatas (L.) Lam) were grown until 2009. From then on, the experiment with onion NTVFS was set up.

At the time of the experimental setup in 2009, soil from the $0-10 \mathrm{~cm}$ layer had the following attributes: $23.2 \mathrm{~g} \mathrm{~kg}^{-1}$ TOC, water $\mathrm{pH}$ 6.0, SMP Index 6.2; available P $26.6 \mathrm{mg} \mathrm{dm}^{-3}$ and exchangeable K 145.2 $\mathrm{mg} \mathrm{dm}^{-3}$ (both extracted by Mehlich-1); exchangeable Al $0.0 \mathrm{cmol}_{\mathrm{c}} \mathrm{kg}^{-1}$, exchangeable $\mathrm{Ca} 7.2 \mathrm{cmol}_{\mathrm{c}} \mathrm{kg}^{-1}$ 
and exchangeable $\mathrm{Mg} 3.4 \mathrm{cmol}_{\mathrm{c}} \mathrm{kg}^{-1}$ (both extracted by $\mathrm{KCl} 1 \mathrm{~mol} \mathrm{~L}^{-1}$ ) (Embrapa, 1997). When the experiment was installed, spontaneous vegetation was desiccated with glyphosate. From then on, no pesticide or herbicide was used.

Treatments consisted of monocropped or intercropped ground cover crops: (1) control with spontaneous vegetation (SV), composed of 20 botanical families, $85 \%$ were: Amaranthaceae (10\%), Asteraceae, Caryophyllaceae, Compositae (10\%), Convolvulaceae, Cruciferae, Cyperaceae (25\%), Euphorbiaceae, Fabaceae, Lamiaceae (10\%), Leguminosae, Liliaceae, Malvaceae, Oxalidaceae (10\%), Plantaginaceae, Poaceae, Polygonaceae (20\%); (2) $100 \%$ black oats, with sowing density (SD) of 120 $\mathrm{kg} \mathrm{ha}^{-1}$; (3) 100\% rye (Secale cereale L.), with SD of $120 \mathrm{~kg} \mathrm{ha}^{-1}$; (4) $100 \%$ oilseed radish (Raphanus sativus L.), with SD of $20 \mathrm{~kg} \mathrm{ha}^{-1}$; (5) oilseed radish $(14 \%)$ and rye (86\%) intercrop, with SD of 10 and $60 \mathrm{~kg} \mathrm{ha}^{-1}$, respectively, and (6) oilseed radish (14\%) and black oats (86\%) intercrop, with SD of 10 and 60 $\mathrm{kg} \mathrm{ha}^{-1}$, respectively. In April 2010, black oats were replaced by barley (Hordeum vulgare L.); from April 2011, barley was again replaced by black oats, due to lack of available barley seeds. The winter species were sown by broadcast in April each year; a grain sowing machine covered the area twice. The amounts of seeds per hectare were based on recommendations by Monegat (1991). Treatments were arranged in randomized blocks, with five replications. Each experimental unit measured $25 \mathrm{~m}^{2}(5 \times 5 \mathrm{~m})$. In July 2009, 2010, 2011, 2012 and 2013, all winter species were rolled down with a knife roller (model RF240, MBO Ltda).

Two other plots were also evaluated, both adjacent to the experiment. The original onion crop area was maintained under CTS for 20 years until 1996, therefore addition of the subsequent years (1996 to 2013) led to a total of 37 years of soil sampling under CTS. The other additional treatment, a secondary forest around 30 years of age, was considered as close to the natural condition of the soil. In 2007, onion under CTS was grown in succession with millet during the summer. Millet was rolled down at flowering with a knife roller, and after 30-60 days the soil was plowed and harrowed to establish the onion crop. Soil was fertilized according to local recommendations (CQFS-SC/RS, 2004); applying $165 \mathrm{~kg} \mathrm{ha}^{-1} \mathrm{P}_{2} \mathrm{O}_{5}$ (triple superphosphate), $105 \mathrm{~kg} \mathrm{ha}^{-1} \mathrm{~K}_{2} \mathrm{O}$ (potassium oxide) and $192 \mathrm{~kg} \mathrm{ha}^{-1}$ $\mathrm{N}$ (ammonium nitrate). In CTS the soil was limed in 2010 to raise water $\mathrm{pH}$ to 6.0 by the SMP method (CQFS RS/SC, 2004).

In NTVFS, in July of each year, after winter cover crops were rolled down, $96 \mathrm{~kg} \mathrm{ha}^{-1} \mathrm{P}_{2} \mathrm{O}_{5}$ (Gafsa phosphate) were applied, plus poultry litter corresponding to $175 \mathrm{~kg} \mathrm{ha}^{-1} \mathrm{P}_{2} \mathrm{O}_{5}, 125 \mathrm{~kg} \mathrm{ha}^{-1} \mathrm{~K}_{2} \mathrm{O}$ and $160 \mathrm{~kg} \mathrm{ha}^{-1} \mathrm{~N}$. Half of the material was applied at onion seedling transplant and half was applied 30 days after planting. No more natural phosphate was applied after 2010, since the content was interpreted as being very high (CQFS-SC/RS, 2004). For onion crop establishment holes were opened in the soil with an adapted no-tillage planter, and onion seedlings cv. 'Empasc 352' - Bola Precoce were transplanted manually. The spacing was $0.50 \mathrm{~m}$ between the rows and $0.10 \mathrm{~m}$ between plants in each row, with 10 onion rows per plot. Manual hoeing was performed at 60 and 90 days after planting. After onions were harvested, in December of each year, mucuna was sown in the entire crop area at SD $120 \mathrm{~kg} \mathrm{ha}^{-1}$. Mucuna was rolled down in March each year, and cover crops were sown in the following month (April). Table 1 shows the mean values for dry matter and onion production in the evaluated areas for 2013, the year of soil sample collection.

\begin{tabular}{|c|c|c|c|}
\hline \multirow{2}{*}{ Treatments } & \multicolumn{2}{|c|}{ Dry matter } & \multirow{2}{*}{$\begin{array}{c}\text { Onion } \\
\text { production }^{(1)}\end{array}$} \\
\hline & Winter & Summer & \\
\hline & \multicolumn{2}{|c|}{$\mathrm{Mg} \mathrm{ha}^{-1}$} & $\mathrm{Mg} \mathrm{ha}^{-1}$ \\
\hline $\begin{array}{l}\text { Spontaneous } \\
\text { vegetation } \\
\text { (control) }\end{array}$ & 4.48 & 2.28 & 16.7 \\
\hline Black oats & 5.22 & 1.95 & 19.9 \\
\hline Rye & 5.64 & 2.29 & 18.9 \\
\hline Oilseed radish & 4.93 & 2.16 & 18.7 \\
\hline $\begin{array}{l}\text { Black oats }+ \\
\text { oilseed radish }\end{array}$ & 5.20 & 2.31 & 18.6 \\
\hline $\begin{array}{l}\text { Rye + oilseed } \\
\text { radish }\end{array}$ & 4.66 & 2.28 & 18.1 \\
\hline CTS & - & 12.00 & 26.1 \\
\hline
\end{tabular}

(1) Onion yield was higher under CTS mainly because of the chemical control of mildew, a fungus disease that may cause losses of over $70 \%$ of onion yield. For NTVFS there are no technologies to reduce the effect of this disease yet.

In September, 2013, five years after implementing the treatments, undeformed soil samples were collected from the $0-5,5-10$ and $10-20 \mathrm{~cm}$ layers by opening small trenches $(0.40 \times 0.40 \times 0.40 \mathrm{~m})$ with a spade. The samples were placed in plastic bags and sent to the laboratory, where they were air-dried and 
cracks or weak spots were manually pounded and then passed through a set of sieves with $8.00 \mathrm{~mm}$ and $4.00 \mathrm{~mm}$ meshes, in order to obtain soil aggregates according to Embrapa (1997). Undeformed samples weighed around 900-1000 grams. In NTVFS and forest, on average the aggregates between $8.00 \mathrm{~mm}>$ $\varnothing \geq 4.0 \mathrm{~mm}$, which were used for the determination of total $\mathrm{C}$ and $\mathrm{N}$ content, as well as $\mathrm{C}$ and $\mathrm{N}$ content in granulometric fractions, represented $\pm 60 \%$ of the total soil weight. In the CTS it did not exceed \pm 30 to $35 \%$ of the total soil mass. Aggregate stability and aggregation rates (mean weighted diameter and geometric diameter of the aggregates, respectively) were measured as described by Loss et al. (2015).

For chemical analyses, aggregates that remained on the $4.00 \mathrm{~mm}$ sieve were manually pounded and passed through a $2.00 \mathrm{~mm}$ sieve, obtaining the airdried thin soil (ADTS) of aggregates. The following parameters were determined: total organic carbon (TOC), total nitrogen (TN), as well as the $\mathrm{C}$ and $\mathrm{N}$ of the granulometric fractions, particulate fractions (POC and PN) and fractions associated with minerals (OCam and Nam). TOC and TN were measured as described by Santos et al. (2017).

Granulometric fractions of SOM were quantified as described by Cambardella \& Elliott (1992). Briefly, $20 \mathrm{~g}$ of ADTS were placed in $60 \mathrm{~mL}$ sodium hexametaphosphate solution $\left(5 \mathrm{~g} \mathrm{~L}^{-1}\right)$, and the samples were stirred for 15 hours on a horizontal shaker. The suspension was then passed through a $53 \mu \mathrm{m}$ sieve with the help of a waterjet. The material that remained in the sieve, which consisted of the particulate carbon and particulate nitrogen (POC/PN), was dried in an oven at $60^{\circ} \mathrm{C}$, quantified for total mass, ground on a porcelain mortar and analyzed for TOC/TN content according to Embrapa (1997). The material, which consisted of carbon and nitrogen associated with minerals (OCam/ Nam), was passed through a $53 \mu \mathrm{m}$ sieve and calculated as the difference between TOC / TN and POC / PN.

The results were analyzed for data normality and homogeneity using the Lilliefors and Bartlett tests, respectively. They were arranged in randomized block design with eight treatments (black oats, rye, oilseed radish, oilseed radish + rye, oilseed radish + black oats, spontaneous vegetation, CTS and forest) and five replications. The results were submitted to analysis of variance and F-tests, and the mean values were compared by the Scott-Knott test when significant, using a critical value of 0.05 .

\section{Results and Discussion}

The highest POC values at all three soil depths and the highest OCam values in the $0-5$ and $10-20 \mathrm{~cm}$ layers were found in the forest area (Figure 1). This is due to the continuous amount of organic matter added to this system, which followed the same pattern shown in TOC (Santos et al., 2017).
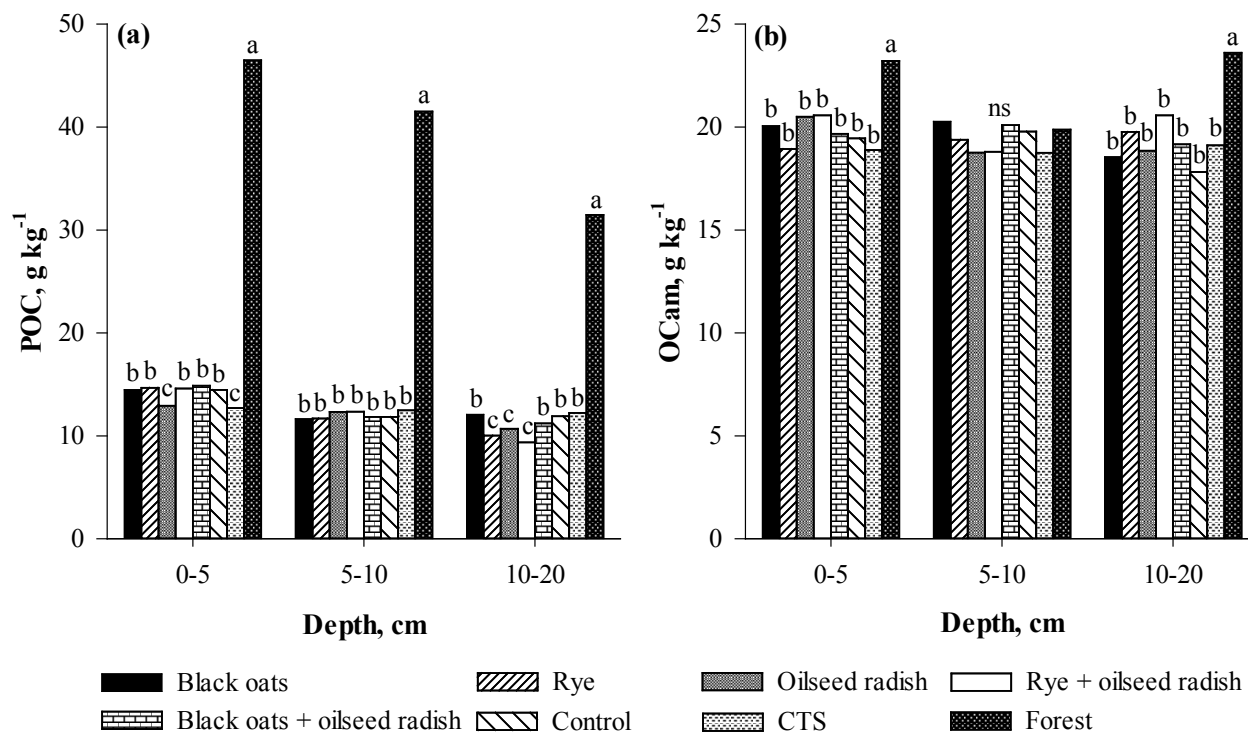

Figure 1. Particulate organic carbon (POC, a); and organic carbon associated with minerals (OCam, b) in soil aggregates for soil use systems with onion crops and forest in Ituporanga, southern Brazil. Different letters for the same attribute, at each depth, indicate significant differences according to the Scott-Knott test $(\mathrm{p}<0.05)$. ns = non-significant according to the F-Test $(\mathrm{p}>0.05)$. 
NTVFS had significantly higher POC in soil aggregates in the 0-5 cm depth compared to CTS, except for the treatment with oilseed radish, which showed no difference from CTS. POC in the $5-10 \mathrm{~cm}$ depth showed no difference between treatments under NTVFS and CTS. In the 10-20 cm layer, treatments with rye and oilseed radish as monocrops and the intercrop with both had the lowest POC values in comparison with all other treatments (Figure 1a).

The low POC value found in the surface soil layer $(0-5 \mathrm{~cm})$ of plots with oilseed radish may be due to the lower lignin and higher cellulose content of this species compared to the other cover plants (Oliveira et al., 2016). Consequently, they decompose more quickly and result in lower soil POC content. These results may also be associated with the root system of this cruciferous species; its axial root produces a greater physical effect on the soil, with lower carbon input through rhizodeposition compared to the other cover species used in NTVFS, which by contrast have a fasciculate root system (Cruciol et al., 2005).

The lowest POC value in CTS plots at the $0-5 \mathrm{~cm}$ depth are due to soil tillage, which causes rupture of aggregates with a consequent exposure of POC protected inside them, thus favoring their rapid decomposition compared to the other treatments. There was no difference in POC between CTS and NTVFS in the $5-10 \mathrm{~cm}$ depth, while there was higher POC in CTS compared to rye, oilseed radish and rye+ oilseed radish in the $10-20 \mathrm{~cm}$ depth. These results may be due to the use of millet as cover plant under CTS, because addition of its residues on the soil surface with later plowing and harrowing caused redistribution of these residues from the surface to the depths of 5-10 and 10-20 cm.

POC in the 10-20 cm depth of NTVFS was higher in treatments with black oats, both as a monocrop and intercropped with oilseed radish, than in treatments with the other cover crops, but did not differ from the treatment with spontaneous vegetation (control). This pattern for the black oat monocrop may be due mainly to its fasciculate and dynamic root system, which is constantly renewed, exploring the soil and favoring decomposition of roots at greater depths. Black oat is a species with a high amount of mass and a high $\mathrm{C} / \mathrm{N}$ ratio. Intercropping black oats with oilseed radish, which has an axial root and a deep root system, promotes physical and chemical effects in depth. The combination favors soil aggregation as well as carbon increase and protection in aggregates, in this case POC, since this fraction is directly related to plant material recently added to the soil (Loss et al., 2015; Wick et al., 2014; Oliveira et al., 2016).

In control treatment plots, diversity of families and species of the spontaneous vegetation also favored soil exploration by root systems, and consequently the input of plant residues through rhizodeposition. In addition, this treatment showed a greater $\mathrm{C} / \mathrm{N}$ ratio compared to the monocrop treatments with oilseed radish and rye at the 10-20 $\mathrm{cm}$ depth (Oliveira et al., 2016). When associated with conservationist management techniques used in NTVFS, spontaneous plants allow a greater increase and protection of $\mathrm{POC}$ inside the aggregates compared to monocropped and intercropped oilseed radish and rye (Figure 1a).

The high TOC (Santos et al., 2017) and POC (Figure 1a) content found in the $0-5 \mathrm{~cm}$ layer in NTVFS plots are due to the use of soil cover (living mulch and/or dead mulch) and the lack of tillage, which favors soil moisture, reduces extreme soil temperatures and slow SOM mineralization compared to CTS (Loss et al., 2011).

There were no differences in OCam among treatments under NTVFS and CTS. The highest OCam values were found in the forest area, in the $0-5$ and $10-20 \mathrm{~cm}$ soil layers (Figure $1 \mathrm{~b}$ ). This fraction showed similar behavior to TOC, for which the forest area also had the highest values (Figure 1a). These results corroborate those reported by Bayer et al. (2004) and Loss et al. (2011), in which the OCam content and stock at greater depths were not influenced by the management systems in use. However, in the present study, in the 0-5 cm layer, there was an $18.7 \%$ reduction in OCam content for CTS compared to the forest area. This reduction was lower in the treatments under NTVFS, except for rye. Comparing lowering in OCam content in NTVFS and CTS in the surface soil layer $(0-5 \mathrm{~cm})$, there was a reduction in the CTS area compared to the other areas of $5.9 ; 0.3 ; 8.0 ; 8.2 ; 4.0$ and $3.0 \%$ for black oats, rye, oilseed radish, oilseed radish+ rye, black oats + oilseed radish and spontaneous vegetation, respectively (Figure 1b). This trend to higher OCam values under NTVFS was reported by Winck et al. (2014), who did not find differences in this fraction under CTS with crop rotation. The trend is due to the greater addition of organic residues by the root system of cover plant species. According to Rasse et al. (2005), stabilization of these organic compounds may be following mechanisms of $\mathrm{C}$ rhizodeposition, leading to this increase in comparison to CTS. 
Table 2. Particulate nitrogen (PN) and nitrogen associated with minerals (Nam) in aggregates of soil under different covers before the onion crop and in forest, in Ituporanga, Brazil.

\begin{tabular}{|c|c|c|c|c|c|c|}
\hline \multirow{3}{*}{ Treatments } & \multicolumn{3}{|c|}{ PN } & \multicolumn{3}{|c|}{ Nam } \\
\hline & \multicolumn{6}{|c|}{ 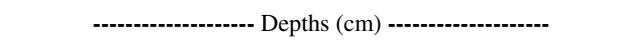 } \\
\hline & $0-5$ & $5-10$ & $10-20$ & $0-5$ & $5-10$ & $10-20$ \\
\hline Black oats & $0.41 \mathrm{c}$ & $0.16 \mathrm{~b}$ & $0.07 \mathrm{c}$ & $1.98 \mathrm{~b}$ & $1.57 \mathrm{~b}$ & $1.32 \mathrm{~b}$ \\
\hline Rye & $0.41 \mathrm{c}$ & $0.18 b$ & $0.17 \mathrm{~b}$ & $1.94 \mathrm{~b}$ & $1.55 \mathrm{~b}$ & $1.38 \mathrm{~b}$ \\
\hline Oilseed radish & $0.33 \mathrm{~d}$ & $0.16 \mathrm{~b}$ & $0.12 \mathrm{c}$ & $2.07 \mathrm{a}$ & $1.75 \mathrm{~b}$ & $1.35 \mathrm{~b}$ \\
\hline $\begin{array}{l}\text { Rye+oilseed } \\
\text { radish }\end{array}$ & $0.44 \mathrm{c}$ & $0.20 \mathrm{~b}$ & $0.07 \mathrm{c}$ & $2.15 \mathrm{a}$ & $1.61 \mathrm{~b}$ & $1.34 \mathrm{~b}$ \\
\hline $\begin{array}{l}\text { Black } \\
\text { oats+oilseed } \\
\text { radish }\end{array}$ & $0.55 b$ & $0.13 b$ & $0.11 \mathrm{c}$ & $2.08 \mathrm{a}$ & $1.40 \mathrm{c}$ & $1.35 \mathrm{~b}$ \\
\hline Control & $0.52 b$ & $0.18 \mathrm{~b}$ & $0.09 \mathrm{c}$ & $1.84 \mathrm{~b}$ & $1.64 \mathrm{~b}$ & $1.31 \mathrm{~b}$ \\
\hline CTS & $0.18 \mathrm{e}$ & $0.15 b$ & $0.19 b$ & $1.67 \mathrm{~b}$ & $1.60 \mathrm{~b}$ & $1.60 \mathrm{a}$ \\
\hline Forest & $2.35 \mathrm{a}$ & $1.31 \mathrm{a}$ & $0.75 \mathrm{a}$ & $2.31 \mathrm{a}$ & $2.08 \mathrm{a}$ & $1.54 \mathrm{a}$ \\
\hline $\mathrm{CV}(\%)$ & 11.11 & 27.4 & 29.93 & 9.68 & 7.76 & 11.25 \\
\hline
\end{tabular}

Means followed by the same letter in a column do not differ from one another according to the Skott-Knott test $(\mathrm{p}>0.05)$. CV $=$ coefficient of variation.

These results showed that CTS hindered maintenance of OCam content compared to the forest and NTVFS. The lower OCam content under CTS is due to lower carbon content in the particulate fraction (POC), due to soil mobilization practices. This causes microorganisms to use organic compounds associated with the surfaces of silt and clay fractions, leading to a decrease in OCam content (Blair et al., 1998).

The forest area showed the highest PN values at all depths analyzed. For the $0-5 \mathrm{~cm}$ depth, the control and black oats+oilseed radish treatments showed high PN values compared to other treatments under NTVFS and CTS. There was no difference between NTVFS and CTS in the 5-10 cm layer; they showed the lowest mean values for this variable. In the $10-20 \mathrm{~cm}$ depth, CTS and rye had higher $\mathrm{PN}$ values than other treatments under NTVFS (Table 2).

The highest nitrogen fraction values associated with minerals (Nam) were found in the forest area at all soil depths. In the treatments with oilseed radish, rye+oilseed radish and black oats+oilseed radish, Nam content was similar to those found in the $0-5 \mathrm{~cm}$ layer of forest soil. In the $5-10 \mathrm{~cm}$ layer, the black oats+oilseed radish intercrop had the lowest Nam values, and in the $10-20 \mathrm{~cm}$ layer there were no differences among treatments under NTVFS. However, the highest Nam values were found in CTS plots and in the forest soil (Table 2).

The low PN content in the $0-5 \mathrm{~cm}$ layer of soil under CTS is due to soil tillage, which affected this $\mathrm{N}$ fraction negatively. When soil aggregates are broken down in tillage, SOM is more easily exposed to attack by microorganisms, which leads to accelerated mineralization, resulting in a rapid decline of soil PN under CTS compared to NTVFS treatments. Since $\mathrm{PN}$ is a key component of SOM, changes to SOM directly affect the dynamics of $\mathrm{N}$ in the soil (Bayer et al., 2000).

TN, as well as TOC (Santos et al., 2017), also undergoes changes when these fractions are affected by management systems, due to the high lability of their particulate fractions ( $\mathrm{POC}$ and $\mathrm{PN}$ ) (Bayer et al., 2004), NTVFS is related to lower impacts on POC and PN, because these fractions physically protect soil aggregates. NTVFS offers greater soil protection due to the restricted soil tillage and cover offered by plants. Therefore it promotes greater protection of SOM against erosive processes, which in turn favors an increase in cation exchange capacity and greater accumulation of TN and TOC (Santos et al., 2017), POC (Figure 1) and PN (Table 2) compared to CTS in the upper soil layer $(0-5 \mathrm{~cm})$.

The oilseed radish monocrop showed the lowest PN value among the treatments under NTVFS, possibly as a result of less chemical effect of this cruciferous species and its lower lignin content (Oliveira et al., 2016), which also resulted in lower POC content (Figure 1a). The highest PN in the black oats+oilseed radish intercrop are possibly due to the 
interaction between the grass and the cruciferous species, favoring the chemical effect of black oats through the release of exudates, as well as the physical effect of oilseed radish as it grows, compressing the soil particles. In the control plots, which had high $\mathrm{PN}$, there was a greater diversity of species that form the soil cover, leading to a similar effect. Therefore, both of these treatments favor the increase of $\mathrm{PN}$ in the aggregates.

The high PN values in the $10-20 \mathrm{~cm}$ layer of soil under CTS may be due to a soil tillage effect, which causes fragmentation and homogenization of millet residues from the surface to the subsequent depths. This behavior was also observed for other fractions of $\mathrm{N}$. In the 10-20 cm layer; both Nam (Table 2) and TN (Santos et al., 2017) had higher values in soil than in other treatments under CTS. The plots with rye did not differ from those under CTS, in the $10-20 \mathrm{~cm}$ layer but, but had higher PN content than all other treatments under NTVFS. This result may be due to the chemical characteristics of rye; since this species has a fasciculate and dense root system, which distributes the root exudates in a more uniform manner (Casali, 2012), PN content may be increased inside the aggregates.

There were greater differences in Nam than in OCam among the systems evaluated. In the $0-5 \mathrm{~cm}$ layer, the treatments with oilseed radish, rye+oilseed radish and black oats+oilseed radish showed Nam contents equal to those of the forest area and higher than the contents found in plots under CTS, control, or with black oats and rye monocrops (Table 2). These results indicate that the oilseed radish monocrop and the oilseed radish+black oats and oilseed radish+rye intercrop treatments were more efficient at increasing Nam content than the other treatments under NTVFS or with CTS. The procedures used in CTS (plowing and harrowing) accelerate Nam mineralization, even using millet as cover plant, as observed for TN (Santos et al., 2017). And even if CTS did not show a significant difference compared to black oats, rye or control treatments under NTVFS, it had greater Nam proportions: $15.7 \%, 14.0 \%$ and $9.2 \%$, respectively, compared to CTS.

The forest area had the highest Nam value in the 5-10 cm layer, while the black oats+oilseed radish intercrop had the lowest value. For the $10-20 \mathrm{~cm}$ layer, in addition to the forest area, CTS also showed the highest Nam value, unlike the other treatments under NTVFS. Considering that black oat is a high phytomass-producing plant and its residues remain on the soil for a relatively long period (Oliveira et al.,
2016), it may be inferred that $\mathrm{N}$ from black oats is released more slowly. This would cause lower Nam values compared to the other treatments, even when black oats are intercropped with oilseed radish. These results corroborate the higher $\mathrm{C} / \mathrm{N}$ ratios found for black oats+oilseed radish at 5-10 cm (Santos, 2016).

The Nam content in CTS, higher than in NTVFS in the deepest soil layer, indicates the action of soil tillage in this system, as the plant residues of millet are incorporated into the soil, thus leading to decomposition and release of $\mathrm{N}$. As a consequence, there is a greater amount of $\mathrm{N}$ associated with silt and clay.

The high Nam values in the $5-10$ and $10-20 \mathrm{~cm}$ layers of the forest area are possibly due to the greater number of sites that are able to bind with chemical elements, including soil $\mathrm{N}$, protecting it and avoiding losses due to leaching or volatilization, as indicated by the highest TOC and TN content in this area (Santos et al., 2017).

The higher content of TOC and TN (Santos et al., 2017), POC (Figure 1a) and PN (Table 2), all in the 0-5 cm layer in NTVFS compared to CTS, is directly related to higher soil aggregation rates (mean weighted diameter and macroaggregates) found in all NTVFS treatments at the 0-5 cm depth (Loss et al., 2015).

NTVFS shows the potential to preserve and increase carbon and nitrogen content in soil aggregates, and consequently reduce damage caused by CTS and contribute to reducing environmental impacts of onion crops on agroecosystems. According to Winck et al. (2014), conservationist management systems such as NTVFS use cover plant species with a root system that is active for a longer time due to the lack of soil preparation such as plowing and harrowing. Conservationist systems have the potential to increase soil $\mathrm{C}$ and $\mathrm{N}$ stocks, mainly in the particulate fraction of SOM, consequently increasing soil quality. This was shown in the present study, in which NTVFS was associated with higher content of TOC and TN (Santos et al., 2017), POC (Figure 1) and PN (Table 2) in the soil upper layer ( $0-5 \mathrm{~cm}$ depth). PN content stands out among the results, since all treatments under NTVFS showed higher values for this variable than plots under CTS. The black oats + oilseed radish treatment stands out among the treatments under NTVFS, in addition to the control treatment. Both treatments had higher $\mathrm{PN}$ values than all other treatments. This variation confirms the sensitivity of this nitrogen compartment (PN) to differentiate crop systems, as observed by Luce et al. $(2013,2014)$. 


\section{Conclusions}

Compared to CTS, NTVFS favored the process of $\mathrm{C}$ and $\mathrm{N}$ content of the granulometric fractions organic matter protection in the superficial soil layer.

UnderNTVFS, the use of black oats and rye increased POC content of both monocropped and intercropped with oilseed radish, as well as the spontaneous vegetation.

Black oats+oilseed radish intercrop and the spontaneous vegetation also contributed to increase the PN content.
Monocrop and the intercrop of oilseed radish increased Nam content; the latter was more efficient than OCam at indicating differences among the evaluated systems.

\section{Acknowledgments}

We thank Chamada MCTI/MAPA/MDA/MEC/ MPA/CNPq N ${ }^{\circ}$ 81/2013 for financial support, and the Estação Experimental da EPAGRI de Ituporanga, SC for making the experimental area availabile.

\section{Literature cited}

Associação Catarinense de Empresas de Tecnologia. 2014. Agronegócio e tecnologia. Santa Catariana. Anuário. Acate. Available: http://www.acate.com.br/sites/default/files/ anuarioacate_0.pdf. Consulted: 03/sep/2015.

Baldock, J.A.; Skjemstad, J.O.

2000. Role of the soil matrix and minerals in protecting natural organic materials against biological attack. Organic Geochemistry, 31: 697-710.

Bayer, C.; Martin-Neto, L.; Mielniczuk, J.; Ceretta, C.A.

2000. Effect of no-till cropping systems on soil organic matter in a sandy clay loam Acrisol from southern Brazil monitored by electron spin resonance and nuclear magnetic resonance. Soil Tillage Research, 53: 95-104.

Bayer, C.; Martin-Neto, L.; Mielniczuk, J.; Pavinato, A.

2004. Armazenamento de carbono em frações lábeis da matéria orgânica de um Latossolo Vermelho sob plantio direto. Pesquisa Agropecuária Brasileira, 39: 677-683.

Blair, G.J.; Chapman, L.; Whitbread, A.M.; Bal-Coelho, B.; Larsen, P.; Tiessen, H.

1998. Soil carbon changes resulting from trash management at two locations in Queensland, Australia and in Nort-east Brazil. Australian Journal of Soil Research, 6: 873-882.

Cambardella, C.A.; Elliott, E.T.

1992. Particulate soil organic-matter changes across a grassland cultivation sequence. Soil Science Society of America Journal, 56: $777-783$.

Casali, C.A.

2012. Sistemas de culturas sob diferentes manejos em longa duração alteram as formas de fósforo do solo? Universidade Federal de Santa Maria, Santa Maria, RS. 149p.

Comissão de Química e Fertilidade do Solo-RS/SC - CQFSRS/SC. 2004. Manual de adubação e de calagem para os estados para os estados do Rio Grande do Sul e Santa Catarina. 10a ed. Sociedade Brasileira de Ciência do Solo. Porto Alegre, Brazil. 400p.

Crusciol, C.A.C.; Cottica, R.L.; Lima, E.V.; Andreotti, M.; Moro,

E.; Marcon, E.

2005. Persistência de palhada e liberação de nutrientes do nabo-forrageiro no plantio direto. Pesquisa Agropecuária Brasileira, 40: 161-168.

Empresa Brasileira de Pesquisa Agropecuária - Embrapa. Centro

Nacional de Pesquisa Agropecuária de Solos.

1997. Manual de Métodos de análise de solo. $2^{\text {a }}$ ed. Rio de Janeiro, Brazil. 212p.
Empresa de Pesquisa Agropecuária e Extensão Rural de Santa Catarina - Epagri.

2013. Sistema de produção para cebola: Santa Catarina ( $4^{\mathrm{a}}$ revisão). EPAGRI. Florianópolis, Brazil. 106 p.

Golchin, A.; Oades, J.M.; Skjemstad, J.O.; Clarke, P. 1994. Soil structure and carbon cycling. Australian Journal of Soil Research, 32: 1043-1068.

Loss, A.; Basso, A.; Oliveira, B.S.; Koucher, L.P.; Oliveira, R.A.;

Kurtz, C.; Lovato, P.E.; Curmi, P.; Brunetto, G; Comin, J.J.

2015. Carbono orgânico total e agregação do solo em sistema de plantio direto agroecológico e convencional de cebola. Revista Brasileira de Ciência do Solo, 39: 1212-1224.

Loss, A.; Pereira, M.G.; Schultz, N.; Anjos, L.H.C.; Silva, E.M.R. 2011. Frações orgânicas e índice de manejo de carbono do solo em diferentes sistemas de produção orgânica. Idesia, 29: 11-19.

Luce, M.S.; Whalen, J.K.; Ziadi, N.; Zebarth, B.J.; Chantigny, M.H. 2014. Labile organic nitrogen transformations in clay and sandyloam soils amended with ${ }^{15} \mathrm{~N}$-labelled faba bean and wheat residues. Soil Biology Biochemistry, 68: 208-218.

Luce, M.S.; Ziadi, N.; Zebarth, B.J.; Whalen, J.; Grant, C.A.; Gregorich, E.G.; Lafond, P.; Blackshaw, R.E.; Johnson, E.N.; O’Donovan, J.T.; Harker, K.N.

2013. Particulate organic matter and soil mineral nitrogen concentrations are good predictors of the soil nitrogen supply to canola following legume and non-legume crops in western Canada. Canadian Journal of Soil Science, 93: 607-620.

Monegat, $\mathrm{C}$.

1991. Manejo de plantas de cobertura do solo - características e manejo em pequenas propriedades. Ed. do Autor. Chapecó, Brazil. 333p.

Oliveira, R.A.; Brunetto, G.; Loss, A.; Gatiboni, L.C.; Kurtz, C.; Muller Junior, V.; Lovato, P.E.; Oliveira, B.S.; Souza, M.; Comin, J.J.

2016. Cover Crops Effects on Soil Chemical Properties and Onion Yield. Revista Brasileira de Ciência do Solo, 40: 01-17.

Rasse, D.P.; Rumpel, C.; Dignac, M.O.

2005. Is soil carbon mostly root carbon? Mechanisms for a specific stabilisation. Plant Soil, 269: 341-356.

Santos, L.H.; Loss, A.; Canton, L.; Ventura, B.S.; Ferreira, G.W.; Kurtz, C.; Brunetto, G.; Lovato, P.E. ; Comin, J.J.

2017. Chemical Properties in Macroaggregates of a Humic Dystrudept Cultivated with Onion under No-Till and Conventional Tillage Systems. Revista Brasileira de Ciencia do Solo, 41: e0160419. 
Soil Survey Staff.

2010. Keys to soil taxonomy. 11.ed. Department of Agriculture. Natural Resources Conservation Service. Washington, DC, US. 338p.
Winck, B.R.; Vezzani, F.M.; Dieckow, J.; Favaretto, N.; Molin, R. 2014. Carbono e nitrogênio NAS frações granulométricas da matéria orgánica do solo, em Sistemas de Culturas sob plantio Direto. . Revista Brasileira de Ciencia do Solo, 38: 980-989. 